Original Research Paper

\title{
Changes in Leaf Characteristics with Tree Age in Dryobalanops beccarii Dyer in a Restored Forest of Sarawak, Malaysia
}

\author{
Emilla Yastari LAPOK, ONG Kian Huat, John Keen CHUBO and Patricia KING Jie Hung \\ Faculty of Agriculture and Food Sciences, Universiti Putra Malaysia Bintulu Sarawak Campus, \\ P.O. Box 396, 97008, Bintulu, Sarawak, Malaysia
}

\section{Article history}

Received: 14-06-2017

Revised: 21-07-2017

Accepted: 09-09-2017

Corresponding Author: ONG Kian Huat,

Faculty of Agriculture and Food Sciences, Universiti Putra Malaysia Bintulu Sarawak Campus, P.O. Box 396, 97008, Bintulu, Sarawak, Malaysia; Email: okhuat@upm.edu.my

\begin{abstract}
Study on leaf properties of an endangered dipterocarp tree species, Dryobalanops beccarii, was conducted in a restored forest. The study focused on the morphology, nutrient concentration and gas exchange in well-developed leaves of $D$. beccarii at different ontogenetic phases. The hypothesis tested that leaf physiological and morphological changes are related to the nutrient concentration level of $D$. beccarii leaves in each ontogenetic phase. Seedling leaves were small and thin, whereas adult tree leaves were the large and thick. The stomata density per unit was abundant in adult tree leaves as compared to seedlings and saplings leaves. The net photosynthetic rate $(\mathrm{Pn})$, transpiration rate $(A)$ and stomatal conductance $\left(g_{s}\right)$ was increased from the seedling phase until the sapling phase, but decreased as the $D$. beccarii reached the mature phase. Scarce stomata density in seedling leaves contributed to low $\mathrm{Pn}, A$ and $g_{s}$, while sapling leaves recorded opposite results due to abundant stomata density accompanied by highest accumulation of nitrogen $(\mathrm{N})$ content per unit leaf area. The low concentration of nitrogen $(\mathrm{N})$, phosphorus (P) and magnesium $(\mathrm{Mg})$ detracted the gas exchange performance. Hence, changes in leaf morphology and physiology of $D$. beccarii were affected by the differences in resource used at each tree ontogenetic phase.
\end{abstract}

Keywords: Dryobalanops beccarii, Leaf Morphology and Physiology, Leaf Nutritional Status, Ontogenetic Phase

\section{Introduction}

The morphological and biological changes of a tree become more complex as the tree grows and aged. In various environment conditions across each ontogenetic phase, the tree increases in size and develops more multipurpose structures (Coste et al., 2009). The changes in traits was experienced by trees in order to maximize fitness in an unpredictable environment (Bazzaz, 1991). The development of tree structures greatly affects the flexibility of leaves morphology and physiology properties. Leaves are of essential importance to a tree, representing their ability to generate power and act as the sensor of the tree towards changes and adaptation in various conditions. Leaf shapes, sizes and durability may absolutely differ as the tree age (Kerstiens, 1996b).

The changes in leaf traits influence the gas exchange performance. The flattened surface gather energy efficiently from sunlight and the underside absorb $\mathrm{CO}_{2}$ and release $\mathrm{O}_{2}$. The thickness of the leaf is optimally minimized, to ease gases diffusion process. On the exterior, leaf has epidermal cell layers that secrete waxy and impermeable cuticle for protection against dehydration (Kerstiens, 1996a). The internal parts of the leaves such as the number of stomata and chlorophyll are directly affecting the gas performance rate. The distribution of stomata vary among leaves depending on the exposure to the environment condition. The abundant number of stomata may increase the photosynthesis, stomatal conductance and transpiration rate (Lawson and Blatt, 2014). However, as the tree aged, the stomatal conductance, photosynthetic rate and transpiration rate vary due to leaves exposure to unpredictable environment conditions in the rainforest and complex tree structures (Day et al., 2001; Hubbard et al., 2001; Yoder et al., 1994).

Apart from leaves morphology, the macronutrient 
mobilization process between leaves is vital in determining the increase and decrease of leaves physiology performance. The mobility of each macronutrient differs depending on the degree of deficiency in the leaves (Avice and Etienne, 2014; Fischer, 2008). The mobile macronutrients such as $\mathrm{N}, \mathrm{P}, \mathrm{K}$ and $\mathrm{Mg}$ are readily translocated from old leaves to new growth, leading to deficiencies in older leaves. While immobile macronutrient, $\mathrm{Ca}$, do not appear to be retranslocated from old leaves to new growth under any circumstances causing the deficiency symptoms to occur generally in young growing areas of the tree (Maillard et al., 2015; Ohe et al., 2005).

Current study involved a dipterocarp tree species, Dryobalanops beccarii Dyer. This species can be found in the south-east of Johore, Peninsular Malaysia and Borneo Island and locally known as kapur merah, kapur bukit and keladan. In the natural forest, this species is a large emergent tree, up to $65 \mathrm{~m}$ tall and usually can be found on shallow leached soils of mixed dipterocarp forests (Ashton, 2004). In Sarawak, D. beccarii is labeled as a vulnerable species, however, nationally and globally, this species is categorized as an endangered species (Ashton, 2004; Julia et al., 2014).

This study was conducted to understand the leaves morphology and physiology responses in a restored forest. The chronosequence method by sequencing observations at different tree growth development phase of $D$. beccarii was applied in multi-cohort stands in the Universiti Putra Malaysia (UPM)-Mitsubishi forest restoration area in Bintulu, Sarawak (Fukami and Wardle, 2005). Hence, the aim of this study was to observe the changes in leaf properties of $D$. beccarii in four different groups of tree stand ages.

\section{Materials and Methods}

\section{Study Site}

The study was conducted in the UPM-Mitsubishi forest restoration area in UPM Bintulu Sarawak Campus, Sarawak, Malaysia $\left(3^{\circ} 12^{\prime} \mathrm{N}, 103^{\circ} 04^{\prime} \mathrm{E}\right)$. The site is situated $60-110 \mathrm{~m}$ above sea level with a mean annual rainfall of $2327 \mathrm{~mm}$. The soil in the area is acidic and classified as Isohyperthermic Typic Dystropept known as the Nyalau soil series ( $\mathrm{Ng}$ et al., 2012). The forest area covers approximately 47.5 ha.

Universiti Putra Malaysia and the Yokohama University of Japan had conducted a research partnership in 1990 with financial support from the Mitsubishi Corporation, Japan to restore abandoned or degraded area (Ng et al., 2012). This project adopted Prof. Akira Miyawaki's ecological technique (Miyawaki, 1999). A collection of indigenous tree species from the nearby natural forests had been used to create a multiple species native forest. Selection of tree species was based on vegetation analyses of nearby areas. Seedlings were densely planted with three plants $\mathrm{m}^{-2}$ and covered with thick mulch after planting without fertilization.

In this study, four different aged group stands were selected, i.e., newly planted-5 year old, 6-10 year old, 11-15 year old and more than 16 year old. The study plots were established where $D$. beccarii was previously planted i.e., P20, plot of 20 years old (established in 1992) located in Phase II and P1, P9 and P14, three plots of 1, 9 and 14 year old respectively (established in 2011, 2003 and 1998) located in Phase IV of the restoration project area. Size of each plot was approximately $30 \times 10 \mathrm{~m}$. In each study plot, four seedlings, saplings and mature trees of $D$. beccarii were selected for measurement. Assessment of tree growth performance was executed every six months for 18 months.

\section{Study of Leaf}

The study was performed twice (Mac-June 2012 and July-September 2013) and was carried out in the laboratory. The length and width of leaves were measured. The leaf area was measured using LI-3100C Area Meter (LI-COR Biosciences, Lincoln, NE). The leaves were cut into $1 \times 1 \mathrm{~cm}$ in order to get images of the cross section, adaxial and abaxial surfaces using an Olympus Fe-320 digital camera. The stomata density and leaf thickness were determined using NIS-Elements Advanced Research Microscope Imaging Software.

Leaf physiology involved measurement of photosynthetic rate, transpiration rate and stomatal conductance. The leaf gas exchange measurement was conducted during a clear day, between 7.30 and 11.30 am using $\mathrm{LCpro}^{+}$Portable Photosynthesis System (ADC BioScientific, Hoddesdon, Herts). The measurement of the leaf gas exchange was divided into ex-situ and in-situ method. The in-situ method was applied on the sapling in P1 where only eight leaves were used for the measurement. The ex-situ was applied for leaves from trees in P9, P14 and P20, where the gas exchange was measured from freshly cut stems. Four fully expanded leaves from each canopy level were selected for the measurement.

The chemical analysis of the leaf was carried out through the wet digestion method. The nutrient elements assessed were $\mathrm{N}, \mathrm{P}, \mathrm{K}, \mathrm{Mg}$ and $\mathrm{Ca}$. The leaves were ovendried at $70^{\circ} \mathrm{C}$ until constant weight was attained and grounded afterward. A $0.2 \mathrm{~g}$ of grounded leaves and $5 \mathrm{ml}$ concentrated $\mathrm{H}_{2} \mathrm{SO}_{4}$ was added in each digestion tube. The samples were heated in the digester. The temperature of the digester was set to increase slowly from $100^{\circ} \mathrm{C}$ for one $\mathrm{h}$ and to $350^{\circ} \mathrm{C}$ for three $\mathrm{h}$. The samples were left to cool down at room temperature before distilled water was added up to $100 \mathrm{ml}$. The solution was analyzed using Atomic 
Absorption Spectrophotometer (AAS Analyst 800, Perkin Elmer Instruments, Norwalk, CT) for $\mathrm{Mg}$, Ca and $\mathrm{K}$ and AutoAnalyzer 3 HR (Seal Analytical, Park Gate, Hants) for $\mathrm{N}$ and $\mathrm{P}$.

\section{Data Analysis}

Differences between the mean values were evaluated using a one-way analysis of variance (ANOVA). Comparison among the means was performed using the Tukey's test and t-Test, calculated at $P<0.05$. Growth models were used in order to determine the most fitted and accurate model on each leaf properties related with age. The models were tested via Linear and Non-Linear (NLIN) procedure. Statistical analysis was performed using SAS for Windows Version 9.13.

\section{Results}

\section{Leaf Morphology}

The leaf morphological parameters increased with age of $D$. beccarii. The leaf area increased slowly as the tree aged. The relationship between leaf area and the stand age was significant $(P<0.05)$, with $\mathrm{R}^{2}=0.99$ (Fig. 1). Leaf area and width in the upper canopy of P14 and P20 was significantly larger $(P<0.05)$ than P1 and P9 (Table 1). Significant difference $(P<0.05)$ was observed between early and final assessment, where leaf width at the beginning was significantly wider $(P<0.05)$ than the final measurement (Table 1). Similar as the leaf area, leaf width also increased with age (Fig. 1). However, since significant different was observed between assessments, two different growth models were developed to show relationship between stand age and leaf width. Both models were significant $(P<0.05)$, with $\mathrm{R}^{2}>0.94$ (Fig. 1).

The leaf length increased with time and the relationship was significant $(P<0.05)$, with $\mathrm{R}^{2}=0.99$ (Fig. $1)$. The leaf length in both upper and lower canopy in P20 was significantly longer $(P<0.05)$ than other stands (Table 1). Leaf thickness in P1 was the lowest among the tree stands (Table 1). The thickness of leaf increased slowly with time and their relationship was significant $(P<0.05)$, with $\mathrm{R}^{2}=0.99$ (Fig. 1$)$. Stomata density was the highest in the lower canopy of P14 and significantly higher $(P<0.05)$ than P20 for both early and final assessments. There was significant difference $(P<0.05)$ between the assessments, where the initial measurements recorded higher stomata density than the final measurement (Table 1). The relationship between stomata density and stand age was significant for both initial and final measurement $\mathrm{R}^{2}=0.99$ (Fig. 1). Both relationships showed that stomata density increased when stand age.

\section{Leaf Physiology}

The rate of photosynthesis and transpiration as well as stomatal conductance were initially increased but decreased later when the stand got older (Fig. 2). Initial measurement recorded the lowest photosynthetic rate in the upper canopy in P1 $\left(2.12 \mu \mathrm{mol} \mathrm{m}^{-2} \mathrm{~s}^{-1}\right)$, while in the upper canopy in $\mathrm{P} 9$ recorded the highest photosynthetic

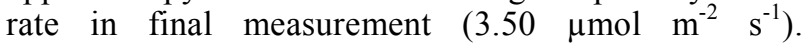
Significant difference $(P<0.05)$ was observed between assessment period where lower photosynthetic values were recorded in the final assessment of P14 and the upper canopy of P20 (Table 2). The relationship between photosynthesis rate and stand age in both measurements were significant, with $\mathrm{R}^{2}=0.99$ (initial) and $\mathrm{R}^{2}=0.63$ (final) (Fig. 2).

Transpiration rate in the initial measurement showed that P20 at the upper canopy was the lowest (Table 2). Similar to photosynthesis rate, the relationship between transpiration rate and stand age was significant, with $\mathrm{R}^{2}=0.65$ (Fig. 2). Similar trend as photosynthetic and transpiration rate, after increasing to the maximum at the age of nine year, stomatal conductance value started to reduce thereafter (Fig. 2). In the initial measurement, comparison between stand age showed that stomatal conductance of the upper canopy of P1 and P20 was significantly lower $(P<0.05)$ than P9 (Table 2$)$.

\section{Leaf Nutrient Concentration}

The concentration of $\mathrm{N}$ decreased as stand aged and the relationship between leaf $\mathrm{N}$ and stand age was significant, with $\mathrm{R}^{2}=0.99$ (Fig. 3). In both initial and final assessments, the upper canopy of P9 recorded the highest N. Significantly higher $(P<0.05) \mathrm{N}$ was found in the initial assessment of $\mathrm{P} 1$ than the final assessment (Table 3). The reduction of $59.6 \%$ in the upper canopy of P1 was significantly lower $(P<0.05)$ than other stands (Table 3). The concentration of $\mathrm{P}$ showed similar reduction trend as leaf $\mathrm{N}$ (Fig. 3). Leaf $\mathrm{P}$ was similar $(0.94-1.12 \%)$ for all stands and canopy levels throughout the assessment period.

The concentration of leaf $\mathrm{K}$ increased slowly over time and their relationship was significant with $\mathrm{R}^{2}=0.99$ (Fig. 3). The lower canopy of P14 recorded almost twice the amount of $\mathrm{K}$ found in P20 (Table 3). Significant difference $(P<0.05)$ was also found in $\mathrm{K}$ between the upper and lower canopies of P20 in the final measurement. In the upper canopy, significantly higher $(P<0.05) \mathrm{P}$ was recorded in $\mathrm{P} 14$ as compared to $\mathrm{P} 1$ and P9 (Table 3). In the initial measurement, leaf $\mathrm{Mg}$ showed a decrease trend over time (Fig. 3), where P20 was significantly lower $(P<0.05)$ than P1 and P9 (Table 3$)$. The relationship between leaf $\mathrm{Mg}$ and stand age was high with $\mathrm{R}^{2}=0.82$ (Fig. 3). The $\mathrm{Ca}$ concentration increased with time and their relationship was significant with $\mathrm{R}^{2}=0.68$ (Fig. 3). In the final measurement, P20 recorded the highest Ca concentration (Table 3). Significant difference $(P<0.05)$ was observed between the two assessments with the initial assessment recording lower $\mathrm{Ca}$ concentration than the final assessment for P20 (Table 3). 

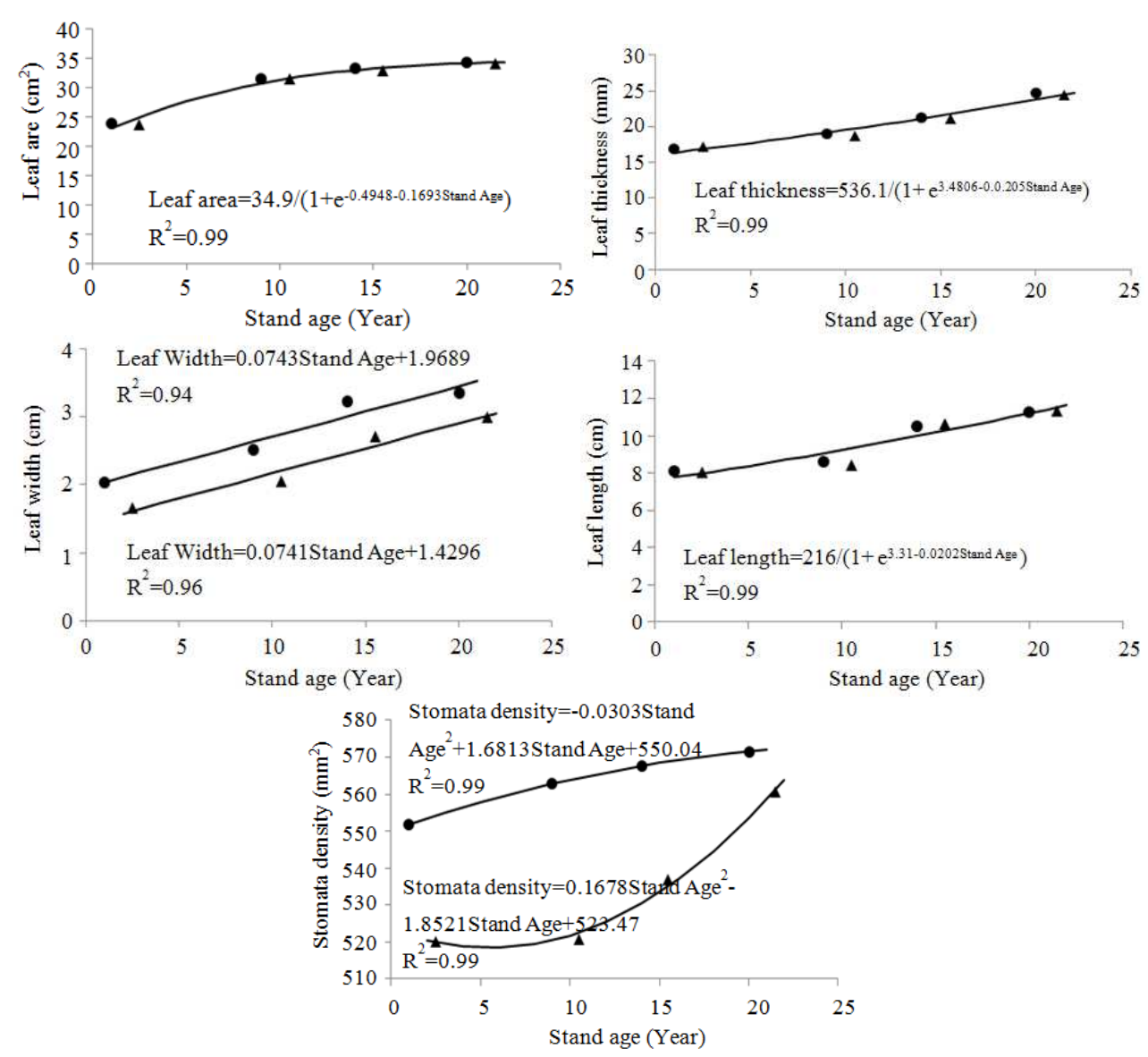

- Initial measurement $\Delta$ Final measurement

Fig. 1. Relationships between Dryobalanops beccarii leaf parameters and stand age
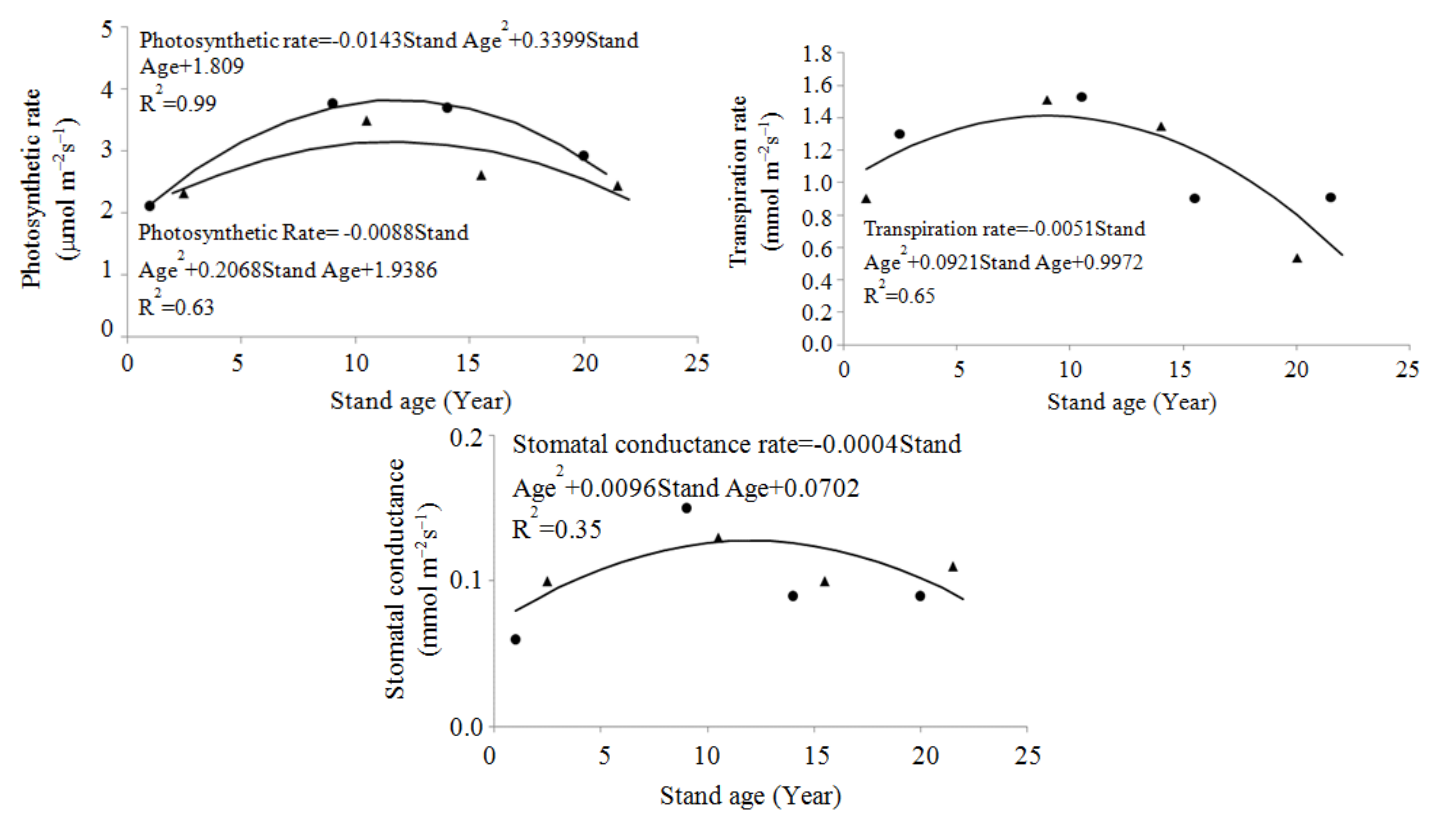

- Initial measurement $\boldsymbol{\Delta}$ Final measurement

Fig. 2. Relationships between leaf physiology and Dryobalanops beccarii stand age 

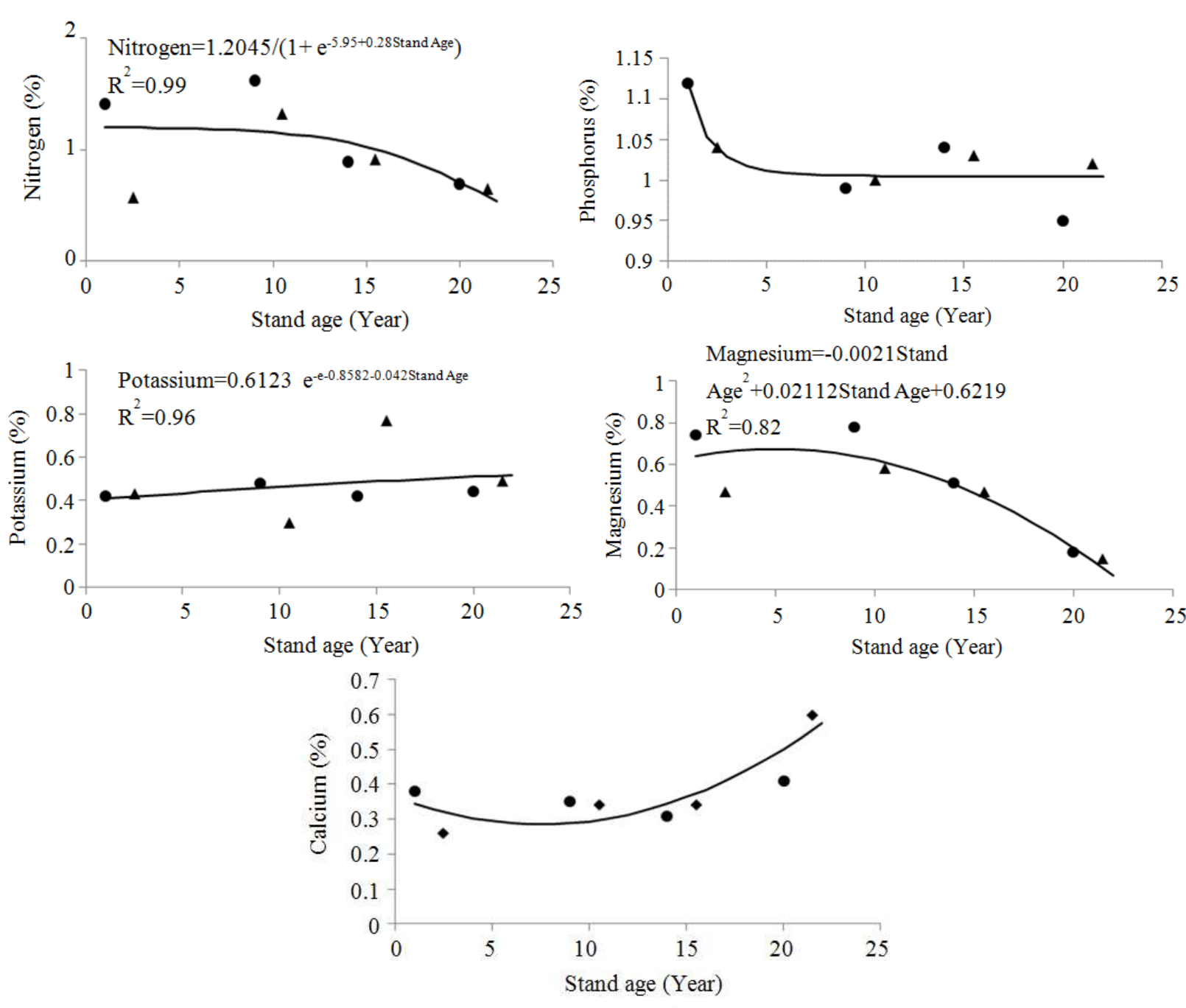

- Initial measurement $\boldsymbol{\Delta}$ Final measurement

Fig. 3. Relationships between leaf nutrient content and Dryobalanops beccarii stand age

Table 1. Leaf morphological characteristics of Dryobalanops beccarii

\begin{tabular}{|c|c|c|c|c|c|c|c|}
\hline \multirow{2}{*}{$\begin{array}{l}\text { Age } \\
\text { Canopy Level }\end{array}$} & & \multirow{2}{*}{$\begin{array}{l}\text { P1 } \\
----- \\
\text { Upper }\end{array}$} & \multirow{2}{*}{$\begin{array}{l}\text { P9 } \\
\text { Upper }\end{array}$} & \multicolumn{2}{|l|}{ P14 } & \multicolumn{2}{|l|}{ P20 } \\
\hline & & & & Upper & Lower & Upper & Lower \\
\hline \multirow[t]{2}{*}{ Leaf Area $\left(\mathrm{cm}^{2}\right)$} & Initial & $24.30 \pm 0.53^{\mathrm{CA}}$ & $31.37 \pm 0.38^{\mathrm{bA}}$ & $33.18 \pm 0.69^{\mathrm{IaA}}$ & $33.52 \pm 0.34^{1 \mathrm{aA}}$ & $34.81 \pm 0.59^{\mathrm{IaA}}$ & $34.19 \pm 0.36^{1 \mathrm{aA}}$ \\
\hline & Final & $23.95 \pm 0.55^{\mathrm{CA}}$ & $31.40 \pm 0.40^{\mathrm{bA}}$ & $32.99 \pm 0.56^{\mathrm{laA}}$ & $33.15 \pm 0.31^{1 \mathrm{aA}}$ & $34.34 \pm 0.62^{1 \mathrm{aA}}$ & $34.02 \pm 0.49^{1 \mathrm{aA}}$ \\
\hline \multirow[t]{2}{*}{ Leaf Width $(\mathrm{cm})$} & Initial & $2.05 \pm 0.04^{\mathrm{cA}}$ & $2.50 \pm 0.07^{\mathrm{bA}}$ & $2.87 \pm 0.17^{\mathrm{laA}}$ & $3.49 \pm 0.16^{\mathrm{laA}}$ & $3.10 \pm 0.12^{1 \mathrm{aA}}$ & $3.58 \pm 0.16^{1 \mathrm{aA}}$ \\
\hline & Final & $1.66 \pm 0.07^{\mathrm{cB}}$ & $2.05 \pm 0.11^{\mathrm{bB}}$ & $2.45 \pm 0.09^{1 \mathrm{aB}}$ & $3.03 \pm 0.13^{1 \mathrm{aB}}$ & $2.49 \pm 0.11^{\mathrm{laB}}$ & $3.36 \pm 0.12^{1 \mathrm{aB}}$ \\
\hline \multirow[t]{2}{*}{ Leaf Length (cm) } & Initial & $8.16 \pm 0.10^{\mathrm{dA}}$ & $8.59 \pm 0.06^{\mathrm{cA}}$ & $10.44 \pm 0.27^{1 \mathrm{bA}}$ & $10.34 \pm 0.40^{1 \mathrm{bA}}$ & $10.81 \pm 0.20^{1 \mathrm{aA}}$ & $11.53 \pm 0.25^{\mathrm{laA}}$ \\
\hline & Final & $8.03 \pm 0.10^{\mathrm{dA}}$ & $8.42 \pm 0.07^{\mathrm{A}}$ & $10.02 \pm 0.15^{1 \mathrm{bA}}$ & $11.11 \pm 0.18^{1 \mathrm{IA}}$ & $10.63 \pm 0.21^{\text {laA }}$ & $11.70 \pm 0.22^{1 \mathrm{aA}}$ \\
\hline \multirow[t]{2}{*}{ Leaf Thickness (mm) } & Initial & $17.13 \pm 0.28^{\mathrm{dA}}$ & $19.01 \pm 0.22^{\mathrm{cA}}$ & $21.85 \pm 0.30^{1 \mathrm{bA}}$ & $20.95 \pm 0.44^{1 \mathrm{bA}}$ & $24.91 \pm 0.38^{\mathrm{laA}}$ & $24.39 \pm 0.44^{1 \mathrm{aA}}$ \\
\hline & Final & $17.68 \pm 0.55^{\mathrm{dA}}$ & $18.62 \pm 0.24^{\mathrm{cA}}$ & $21.48 \pm 0.32^{1 \mathrm{bA}}$ & $20.29 \pm 0.46^{1 \mathrm{bA}}$ & $24.57 \pm 0.47^{1 \mathrm{aA}}$ & $24.46 \pm 1.68^{1 \mathrm{aA}}$ \\
\hline \multirow[t]{2}{*}{ Stomata Density $\left(\mathrm{mm}^{-2}\right)$} & Initial & $556.4 \pm 20.6^{\mathrm{abA}}$ & $567.4 \pm 11.6^{\mathrm{abA}}$ & $530.2 \pm 18.0^{2 \mathrm{bA}}$ & $611.1 \pm 41.4^{1 \mathrm{aA}}$ & $594.8 \pm 18.5^{\text {laA }}$ & $583.9 \pm 19.2^{1 \mathrm{bA}}$ \\
\hline & Final & $520.7 \pm 21.3^{\mathrm{abB}}$ & $523.0 \pm 11.8^{\mathrm{abB}}$ & $502.7 \pm 19.3^{2 \mathrm{bB}}$ & $568.7 \pm 11.0^{1 \mathrm{aB}}$ & $561.6 \pm 22.8^{1 \mathrm{aB}}$ & $570.8 \pm 19.2^{1 \mathrm{aB}}$ \\
\hline
\end{tabular}

Means with standard deviation represented by different superscript lowercase alphabets indicates significant differences between different ages in the upper canopy (P1, P9, P14, P20) by Tukey's test at $\mathrm{p}<0.05$ and the lower canopy (P14 and P20) by t-Test.

Means with standard deviation represented by different superscript numbers indicates significant differences between canopy levels (P14 and P20) by t-Test.

Means with standard deviation represented by different superscript uppercase alphabets indicates significant differences between assessment dates (initial and final) by t-Test. 
Table 2. Leaf physiological characteristics of Dryobalanops beccarii

\begin{tabular}{|c|c|c|c|c|c|c|c|}
\hline \multirow[b]{2}{*}{ Age } & \multirow[b]{2}{*}{ Canopy level } & \multicolumn{2}{|c|}{ Photosynthetic rate $\left(\mu \mathrm{mol} \mathrm{m} \mathrm{m}^{-2} \mathrm{~s}^{-1}\right)$} & \multicolumn{2}{|c|}{ Transpiration rate $\left(\mathrm{mmol} \mathrm{m}^{-2} \mathrm{~s}^{-1}\right)$} & \multicolumn{2}{|c|}{ Stomatal conductance $\left(\mathrm{mmol} \mathrm{m}^{-2} \mathrm{~s}^{-1}\right)$} \\
\hline & & Initial & Final & Initial & Final & Initial & Final \\
\hline P1 & Upper & $2.12 \pm 0.49^{\mathrm{bA}}$ & $2.32 \pm 0.60^{\mathrm{bA}}$ & $0.93 \pm 0.57^{\mathrm{aA}}$ & $1.31 \pm 1.36^{\mathrm{aA}}$ & $0.06 \pm 0.02^{\mathrm{bA}}$ & $0.10 \pm 0.05^{\mathrm{aA}}$ \\
\hline P9 & Upper & $3.78 \pm 0.55^{\mathrm{aA}}$ & $3.50 \pm 0.91^{\mathrm{aA}}$ & $1.51 \pm 0.31^{\mathrm{aA}}$ & $1.53 \pm 0.46^{\mathrm{aA}}$ & $0.17 \pm 0.07^{\mathrm{aA}}$ & $0.13 \pm 0.07^{\mathrm{aA}}$ \\
\hline \multirow[t]{2}{*}{ P14 } & Upper & $3.96 \pm 0.54^{1 \mathrm{aA}}$ & $2.68 \pm 0.17^{1 \mathrm{bB}}$ & $1.59 \pm 0.50^{1 \mathrm{aA}}$ & $1.03 \pm 0.41^{1 \mathrm{aA}}$ & $0.10 \pm 0.05^{1 \mathrm{abA}}$ & $0.08 \pm 0.07^{1 \mathrm{aA}}$ \\
\hline & Lower & $3.35 \pm 0.95^{1 \mathrm{aA}}$ & $2.56 \pm 0.61^{1 \mathrm{aB}}$ & $1.11 \pm 0.48^{1 \mathrm{aA}}$ & $0.77 \pm 0.44^{1 \mathrm{aA}}$ & $0.08 \pm 0.06^{1 \mathrm{aA}}$ & $0.12 \pm 0.13^{1 \mathrm{aA}}$ \\
\hline \multirow[t]{2}{*}{$\mathrm{P} 20$} & Upper & $3.26 \pm 1.12^{1 \mathrm{aA}}$ & $2.49 \pm 0.61^{1 \mathrm{bB}}$ & $0.46 \pm 0.23^{1 \mathrm{bA}}$ & $0.97 \pm 0.42^{1 \mathrm{aA}}$ & $0.07 \pm 0.05^{1 \mathrm{bA}}$ & $0.13 \pm 0.08^{1 \mathrm{aA}}$ \\
\hline & Lower & $2.59 \pm 1.83^{1 \mathrm{aA}}$ & $2.40 \pm 0.85^{1 \mathrm{aA}}$ & $0.61 \pm 0.29^{1 \mathrm{aA}}$ & $0.85 \pm 0.40^{1 \mathrm{aA}}$ & $0.11 \pm 0.08^{1 \mathrm{aA}}$ & $0.09 \pm 0.05^{1 \mathrm{aA}}$ \\
\hline
\end{tabular}

Means with standard deviation represented by different superscript lowercase alphabets indicates significant differences between different ages in the upper canopy (P1, P9, P14, P20) by Tukey's test at $\mathrm{p}<0.05$ and the lower canopy (P14 and P20) by t-Test.

Means with standard deviation represented by different superscript numbers indicates significant differences between canopy levels (P14 and P20) by t-Test.

Means with standard deviation represented by different superscript uppercase alphabets indicates significant differences between assessment dates (initial and final) by t-Test

Table 3. Leaf nutrient properties of Dryobalanops beccarii

\begin{tabular}{|c|c|c|c|c|c|c|c|}
\hline \multirow{2}{*}{$\begin{array}{l}\text { Age } \\
\text { Canopy level }\end{array}$} & & \multirow{2}{*}{$\begin{array}{l}\text { P1 } \\
------ \\
\text { Upper }\end{array}$} & \multirow{2}{*}{$\begin{array}{l}\text { P9 } \\
- \text { Upper }\end{array}$} & \multicolumn{2}{|l|}{ P14 } & \multicolumn{2}{|l|}{ P20 } \\
\hline & & & & Upper & Lower & Upper & Lower \\
\hline \multirow[t]{2}{*}{ Nitrogen (\%) } & Initial & $1.41 \pm 3.05^{\mathrm{aA}}$ & $1.32 \pm 0.80^{\mathrm{aA}}$ & $0.92 \pm 0.21^{1 \mathrm{aA}}$ & $0.86 \pm 0.27^{1 \mathrm{IAA}}$ & $0.64 \pm 0.16^{1 \mathrm{aA}}$ & $0.73 \pm 0.06^{1 \mathrm{a} A}$ \\
\hline & Final & $0.57 \pm 0.71^{\mathrm{aB}}$ & $1.32 \pm 0.80^{\mathrm{aA}}$ & $0.97 \pm 0.56^{1 \mathrm{aA}}$ & $0.84 \pm 0.24^{1 \mathrm{aA}}$ & $0.64 \pm 0.16^{1 \mathrm{aA}}$ & $0.65 \pm 0.16^{1 \mathrm{aA}}$ \\
\hline \multirow[t]{2}{*}{ Phosphorus (\%) } & Initial & $1.12 \pm 0.06^{\mathrm{aA}}$ & $0.99 \pm 0.14^{\mathrm{aA}}$ & $1.05 \pm 0.01^{1 \mathrm{aA}}$ & $1.03 \pm 0.02^{1 \mathrm{aA}}$ & $0.96 \pm 0.17^{1 \mathrm{aA}}$ & $0.94 \pm 0.06^{1 \mathrm{aA}}$ \\
\hline & Final & $1.04 \pm 0.12^{\mathrm{aA}}$ & $1.00 \pm 0.13^{\mathrm{aA}}$ & $1.02 \pm 0.03^{1 \mathrm{aA}}$ & $1.04 \pm 0.02^{1 \mathrm{aA}}$ & $1.04 \pm 0.02^{1 \mathrm{aA}}$ & $1.00 \pm 0.02^{1 \mathrm{aA}}$ \\
\hline \multirow[t]{2}{*}{ Potassium (\%) } & Initial & $0.42 \pm 0.25^{\mathrm{aA}}$ & $0.48 \pm 0.43^{\mathrm{aA}}$ & $0.41 \pm 0.30^{1 \mathrm{aA}}$ & $0.43 \pm 0.19^{1 \mathrm{aA}}$ & $0.46 \pm 0.25^{1 \mathrm{aA}}$ & $0.41 \pm 0.20^{1 \mathrm{aA}}$ \\
\hline & Final & $0.43 \pm 0.30^{\mathrm{bA}}$ & $0.30 \pm 0.11^{\mathrm{bA}}$ & $0.80 \pm 0.24^{1 \mathrm{aA}}$ & $0.74 \pm 0.35^{1 \mathrm{aA}}$ & $0.58 \pm 0.18^{1 \mathrm{abA}}$ & $0.39 \pm 0.12^{2 \mathrm{bA}}$ \\
\hline \multirow[t]{2}{*}{ Magnesium (\%) } & Initial & $0.78 \pm 0.02^{\mathrm{aA}}$ & $0.74 \pm 0.14^{\mathrm{aA}}$ & $0.40 \pm 0.10^{1 \mathrm{abA}}$ & $0.62 \pm 0.03^{1 \mathrm{aA}}$ & $0.12 \pm 0.08^{1 \mathrm{bA}}$ & $0.23 \pm 0.10^{1 \mathrm{bA}}$ \\
\hline & Final & $0.47 \pm 0.02^{\mathrm{abA}}$ & $0.58 \pm 0.02^{\mathrm{aA}}$ & $0.32 \pm 0.01^{1 \mathrm{abA}}$ & $0.61 \pm 0.02^{1 \mathrm{aA}}$ & $0.11 \pm 0.02^{1 \mathrm{bA}}$ & $0.18 \pm 0.341^{\mathrm{bA}}$ \\
\hline \multirow[t]{2}{*}{ Calcium (\%) } & Initial & $0.39 \pm 0.01^{\mathrm{aA}}$ & $0.37 \pm 0.03^{\mathrm{aA}}$ & $0.32 \pm 0.04^{1 \mathrm{aA}}$ & $0.30 \pm 0.01^{1 \mathrm{aA}}$ & $0.40 \pm 0.01^{1 \mathrm{aA}}$ & $0.42 \pm 0.06^{1 \mathrm{aA}}$ \\
\hline & Final & $0.24 \pm 0.03^{\mathrm{bA}}$ & $0.29 \pm 0.04^{\mathrm{bA}}$ & $0.38 \pm 0.17^{1 \mathrm{bA}}$ & $0.31 \pm 0.10^{1 \mathrm{bA}}$ & $0.61 \pm 0.49^{1 \mathrm{aB}}$ & $0.60 \pm 1.70^{1 \mathrm{aB}}$ \\
\hline
\end{tabular}

Means with standard deviation represented by different superscript lowercase alphabets indicates significant differences between different ages in the upper canopy (P1, P9, P14, P20) by Tukey's test at $\mathrm{p}<0.05$ and the lower canopy (P14 and P20) by t-Test.

Means with standard deviation represented by different superscript numbers indicates significant differences between canopy levels (P14 and P20) by t-Test.

Means with standard deviation represented by different superscript uppercase alphabets indicates significant differences between assessment dates (initial and final) by t-Test.

\section{Discussion}

As tree grow taller with age, the tree tend to develop large size leaves when exposed to the combination of mesic condition and high solar radiation (Givnish and Vermeij, 1976). Matured trees are expected to develop larger leaves than juvenile trees (Martínez-Garza and Howe, 2005). Thus, leaves of matured D. beccarii showed greater length, width, thickness and leaf area than leaves of juvenile $D$. beccarii. The comparison of leaf size between the canopy levels showed no significant difference found, neither in terms of leaf area, length, width, nor thickness. This was in contrast to the understanding that leaf in the upper canopy (sun leaves) is commonly smaller but thicker than leaf in the lower canopy (shade leaves) (Givnish, 1988; Keller, 2015; Pallardy, 2008).

Stomata density is influenced by atmospheric $\mathrm{CO}_{2}$ concentration. The $\mathrm{CO}_{2}$ concentration is different at every elevation or canopy height, where it is low at high canopy level and vice versa (Buchmann et al., 1996).
There is usually a reduction in stomatal density accompanied with increasing $\mathrm{CO}_{2}$ (Woodward and Kelly, 1995). Hence, higher stomata density in matured $D$. beccarii as comparesd to juvenile $D$. beccarii may due to lower $\mathrm{CO}_{2}$ concentration at the higher canopy level. Stomata density is also affected by the radiation exposure and water loss. The size of $D$. beccarii leaves during the seedling phase was small than other phases. The leaf form has strong association with the sapling architectural form (King and Maindonald, 1999), of which the seedling and sapling of D. beccarii is classified as plagiotropic with simple sun leaves (Turner, 2001). Sun leaves have higher stomata density while shade leaves showed the opposite trend (Givnish, 1988; Keller, 2015; Pallardy, 2008). However, current results was found to be contradicted with other findings, where the stomata density was fewer in sun leaves than in shade leaves of P14.

Gas exchange is influenced by leaf properties and environmental factors such as light, temperature, nutrition and water availability (Aighewi and Ekanayake, 
2004; Xie and Luo, 2003). Since the photosynthetic rate, transpiration rate and stomatal conductance was positively correlated with each other, the reduction of one of these parameters will be followed by reduction of the others two in order to maintain a functional homeostasis (Evans and Poorter, 2001; Saliendra et al., 1995; Yoder et al., 1994). Seedling of D. beccarii recorded lowest leaf area, length, thickness and width. These characteristic enhance the adaptability of seedlings to prevent dehydration in open area, although it may contributed to low efficiency of photosynthesis, transpiration and stomatal conductance rate (Chang and Miller, 2004; Greer and Halligan, 2001). Saplings of $D$. beccarii in lesser stand density recorded considerably high photosynthetic rate, transpiration rates and stomatal conductance. In less dense stand, there were substantial gaps between the saplings, allowing the leaves surface to be exposed directly to the environmental factors such as high irradiance and wind (Lowman et al., 2012). The exposure of leaves to high light intensity, temperature and wind speed increases the transpiration rate, of which led to high photosynthesis and transpiration rate (Kirkham, 2000; Toole and Toole, 2002).

The saplings (P14) in high stand density and matured $D$. beccarii showed reduction of transpiration and photosynthetic rates and stomatal conductance. In high density stand where the saplings grew too close to each other as well as in matured $D$. beccarii stand where there were massive canopy size and root system, led to overlapping canopies and limited space causing the saplings to compete for limited resources. The stomatal conductance decreased due to the limitation of $\mathrm{CO}_{2}$ as the $\mathrm{CO}_{2}$ mitigation in dense stand was higher than sparse or open stand (Del Pozo et al., 2007). Meanwhile, the competition to absorb water in the soil through overlapping root system (Manoli et al., 2014) directly reduce water availability for transpiration (Prieto et al., 2012). The rate of photosynthesis declined due to sunlight obstructed by the canopy layer through selfshading or being shaded by nearby trees (Gundel et al., 2014; Manoli et al., 2014; Ng et al., 2016).

The concentration of $\mathrm{N}, \mathrm{P}$ and $\mathrm{Mg}$ of $D$. beccarii was slowly reduced from seedling to mature phase. Unlike $\mathrm{N}$ and $\mathrm{Mg}, \mathrm{P}$ was decreased tremendously during seedling phase and become almost plateau in sapling and mature phase. The $\mathrm{N}, \mathrm{P}$ and $\mathrm{Mg}$ are key nutrients that influence a number of important leaf traits, which vary in the use and allocation between leaves. These $\mathrm{N}, \mathrm{P}$ and $\mathrm{Mg}$ are highly mobile and always being remobilized in young leaves (Avice and Etienne, 2014; Fischer, 2008; Mediavilla and Escudero, 2003), causing deficiency symptom in old leaves. The inadequate supply of $\mathrm{N}, \mathrm{P}$ and $\mathrm{Mg}$ in soil may reduce the $\mathrm{N}, \mathrm{P}$ and $\mathrm{Mg}$ in the leaves over time. The supply of nutrients from soil was highly dependent on the decomposition of accumulated organic matter since there was no fertilizer application in the study plots. The cation that competes with $\mathrm{Mg}$ in uptake, such as $\mathrm{K}$, also cause leaf $\mathrm{Mg}$ to decrease (Mengel et al.,
2012). Leaf $\mathrm{K}$ and $\mathrm{Ca}$ were increased as D. beccarii aged. The increased of $\mathrm{K}$ maybe related to the accumulation of $\mathrm{K}$ in the leaf as leaf aged and only being mobilized to young expanding leaves under conditions of $\mathrm{K}$ deficiency (Lin and Yeh, 2008). The leaf $\mathrm{Ca}$ possessed high in mobility, causing the $\mathrm{Ca}$ to accumulate in the leaf as the leaf aged (Suárez, 2010).

\section{Conclusion}

Leaf size increased with stand age although the leaf width declined. The leaf morphology was found to be significantly correlated with the tree morphology parameters, except for leaf width and canopy diameter. The sun leaf was similar to the shade leaf. The stomata density reduced during yearly assessment in each stand age. The photosynthetic rate, transpiration rate and stomatal conductance showed similar pattern where these three parameters was low in the freshly emerged saplings, increased rapidly until $D$. beccarii aged approximately 9-14 year old and decreased once it reached the mature phase. The transpiration rate was positively affected by the leaf thickness and length as well as leaf width. The negative correlation of N, P and $\mathrm{K}$ may have caused the deficit of photosynthesis rate, transpiration rate and stomatal conductance.

\section{Acknowledgement}

Sincere gratitude to George Bala Empin, Khairul Annuar Mohd. Suhailiee, Muaish Sait and Sylvester Sam for the field assistance.

\section{Funding Information}

This research was supported by the Universiti Putra Malaysia under the Research University Grant Scheme (03/04/11/1469RU).

\section{Author's Contributions}

Emilla Yastari LAPOK: Involved in all experiments, field work, coordinated data analyses and contributed to the scientific writing of the manuscript.

ONG Kian Huat: Project leader, involved in the supervision of the research, field work, data analyses, editing and proofreading of the manuscript.

John Keen CHUBO: Involved in the supervision of the research and editing of the manuscript.

Patricia KING Jie Hung: Involved in the supervision of the research.

\section{Ethics}

The authors declare no conflicts of interest and this article is original and contains unpublished material in accordance with the ethical standards specified by the OnLine Journal of Biological Sciences. 


\section{References}

Aighewi, B.A. and I.J. Ekanayake, 2004. In-situ chlorophyll fluorescence and related growth of white Guinea yam at different ages. Tropical Sci., 44: 201-206.

Ashton, P.S., 2004. Dipterocarpaceae. In: Tree Flora of Sabah and Sarawak Volume 5, Soepadmo E., L.G. Saw and R.C.K. Chung (Eds.), Government of Malaysia, Kuala Lumpur, pp: 63-388.

Avice, J.C. and P. Etienne, 2014. Leaf senescence and nitrogen remobilization efficiency in oilseed rape (Brassica napus L.). J. Exp. Botany, 65: 3813-3824.

Bazzaz, F.A., 1991. Habitat selection in plants. Am. Naturalist, 137: 116-130.

Buchmann, N., W.Y. Kao and J.R. Ehleringer, 1996. Carbon dioxide concentrations within forest canopies-variation with time, stand structure and vegetation type. Global Change Biol., 2: 421-432.

Chang, Y.C. and W.B. Miller, 2004. The relationship between leaf enclosure, transpiration and upper leaf necrosis on Lilium Star 'Gazer'. J. Am. Society Horticultural Sci., 129: 128-133.

Coste, S., J.C. Roggy, L. Garraud, P. Heuret and E. Nicolini et al., 2009. Does ontogeny modulate irradiance-elicited plasticity of leaf traits in saplings of rain-forest tree species? A test with Dicorynia guianensis and Tachigali melinonii (Fabaceae, Caesalpinioideae). Ann. Forest Sci., 66: 1-12.

Day, M.E., M.S. Greenwood and A.S. White, 2001. Agerelated changes in foliar morphology and physiology in red spruce and their influence on declining photosynthetic rates and productivity with tree age. Tree Physiology, 21: 1195-1204.

Del Pozo, A., P. Pérez, D. Gutiérrez, A. Alonso and R. Morcuende et al., 2007. Gas exchange acclimation to elevated $\mathrm{CO}_{2}$ in upper-sunlit and lower-shaded canopy leaves in relation to nitrogen acquisition and partitioning in wheat grown in field chambers. Environ. Exp. Botany, 59: 371-380.

Evans, J. and H. Poorter, 2001. Photosynthetic acclimation of plants to growth irradiance: The relative importance of specific leaf area and nitrogen partitioning in maximizing carbon gain. Plant, Cell Environ., 24: 755-767.

Fischer, A.M., 2007. Nutrient Remobilization During Leaf Senescence. In: Annual Plant Reviews Volume 26: Senescence Processes in Plants, Gan, S. (Ed.), Blackwell Publishing Ltd, Oxford, pp: 87-107.

Fukami, T. and D.A. Wardle, 2005. Long-term ecological dynamics: Reciprocal insights from natural and anthropogenic gradients. Proc. Biol. Sci., 272: 2105-2115. DOI: 10.1098/rspb.2005.3277

Givnish, T.J., 1988. Adaptation to sun and shade: A wholeplant perspective. Functional Plant Biol., 15: 63-92.

Givnish, T.J. and G.J. Vermeij, 1976. Sizes and shapes of liane leaves. Am. Naturalist, 110: 743-778.
Greer, D.H. and E.A. Halligan, 2001. Photosynthetic and fluorescence light responses for kiwifruit (Actinidia deliciosa) leaves at different stages of development on vines grown at two different photon flux densities. Functional Plant Biol., 28: 373-382.

Gundel, P.E., R. Pierik, L. Mommer and C.L. Ballaré, 2014. Competing neighbors: Light perception and root function. Oecologia, 176: 1-10.

Hubbard, R.M., M.G. Ryan, V. Stiller and J.S. Sperry, 2001. Stomatal conductance and photosynthesis vary linearly with plant hydraulic conductance in ponderosa pine. Plant, Cell Environ., 24: 113-121.

Julia, S., L. Chong, B. Vilma and S. Esther, 2014. Sarawak Plant Red List: Dipterocarpaceae: Series I: Dipterocarpus, Dryobalanops and Shorea. 1st Edn., Sarawak Forestry Corporation, Kuching, ISBN-10: 9834355386, pp: 193.

Keller, M., 2015. The Science of Grapevines: Anatomy and Physiology. 2nd Edn., Academic Press/Elsevier, Amsterdam, ISBN-10: 0124199879, pp: 509.

Kerstiens, G., 1996a. Plant cuticles-An integrated functional approach. J. Exp. Botany, 47: 50-60.

Kerstiens, G., 1996b. Signalling across the divide: A wider perspective of cuticular structure-function relationships. Trends Plant Sci., 1: 125-129.

King, D.A. and J.H. Maindonald, 1999. Tree architecture in relation to leaf dimensions and tree stature in temperate and tropical rain forests. J. Ecol., 87: 1012-1024.

Kirkham, M.B., 1999. Water Use in Crop Production. 1st Edn., CRC Press, ISBN-10: 1560220686, pp: 385.

Lawson, T. and M.R. Blatt, 2014. Stomatal size, speed and responsiveness impact on photosynthesis and water use efficiency. Plant Physiol., 164: 1556-1570.

Lin, C.Y. and D.M. Yeh, 2008. Potassium nutrition affects leaf growth, anatomy and macroelements of Guzmania. Hort. Sci., 43: 146-148.

Lowman, M.D., T. Schowalter and J. Franklin, 2012. Methods in Forest Canopy Research. 1st Edn., University of California Press, Berkeley, ISBN-10: 0520953924, pp: 240.

Maillard, A., S. Diquélou, V. Billard, P. Laîné and M. Garnica et al., 2015. Leaf mineral nutrient remobilization during leaf senescence and modulation by nutrient deficiency. Frontiers Plant Sci., 6: 317-317.

Manoli, G., S. Bonetti, J.C. Domec, M. Putti and G. Katul et al., 2014. Tree root systems competing for soil moisture in a 3D soil-plant model. Adv. Water Resources, 66: 32-42.

Martínez-Garza, C. and H.F. Howe, 2005. Developmental strategy or immediate responses in leaf traits of tropical tree species? Int. J. Plant Sci., 166: 41-48. 
Mediavilla, A. and S. Escudero, 2003. Decline in photosynthetic nitrogen use efficiency with leaf age and nitrogen resorption as determinants of leaf life span. J. Ecol., 91: 880-889.

Mengel, K., E.A. Kirkby, H. Kosegarten and T. Appel, 2012. Principles of Plant Nutrition. 5th Edn., Springer Science and Business Media, Dordrecht, ISBN-10: 9401010099 , pp: 849.

Miyawaki, A. 1999. Creative ecology. Plant Biotechnol., 16: $15-25$.

Ng, C.W.W., J. Ni, A.K. Leung, C. Zhou and Z. Wang, 2016. Effects of planting density on tree growth and induced soil suction. Geotechnique Int. J. Soil Mechanics, 55: 1-14.

Ohe, M., M. Rapolu, T. Mieda, Y. Miyagawa and Y. Yabuta et al., 2005. Decline in leaf photo oxidative-stress tolerance with age in tobacco. Plant Sci., 168: 1487-1493.

Pallardy, S.G., 2008. Physiology of Woody Plants. 3rd Edn., Academic Press, Amsterdam, ISBN-10: 0080568718, pp: 464.

Prieto, I., C. Armas and F.I. Pugnaire, 2012. Water release through plant roots: New insights into its consequences at the plant and ecosystem level. New Phytologist, 193: 830-841.
Saliendra, N.Z., J.S. Sperry and J.P. Comstock, 1995. Influence of leaf water status on stomatal response to humidity, hydraulic conductance and soil drought in Betula occidentalis. Planta, 196: 357-366.

Suárez, N., 2010. Leaf lifetime photosynthetic rate and leaf demography in whole plants of Ipomoea pescaprae growing with a low supply of calcium, a "non-mobile" nutrient. J. Exp. Botany, 61: 843-855.

Toole, A.G. and S.M. Toole, 2002. Essential as Biology. Nelson Thornes, Cheltenham. ISBN-10: 9780748765058, pp: 280.

Turner, I.M., 2001. The Ecology of Trees in the Tropical Rain Forest. 1st Edn., Cambridge University Press, Cambridge, ISBN-10: 9780511542206, pp: 316.

Woodward, F.I. and C.K. Kelly, 1995. The influence of $\mathrm{CO}_{2}$ concentration on stomatal density. New Phytologist, 131: 311-327.

Xie, S. and X. Luo, 2003. Effect of leaf position and age on anatomical structure, photosynthesis, stomatal conductance and transpiration of Asian pear. Botanical Bull. Acad. Sinica, 44: 297-303.

Yoder, B.J., M.G. Ryan, R.H. Waring, A.W. Schoettle and M.R. Kaufmann, 1994. Evidence of reduced photosynthetic rates in old trees. Forest Sci., 40: 513-527. 